\title{
Analisa Hasil Prediksi Metode Least Square menggunakan Korelasi dan MAPE pada Toko PS
}

\author{
Daniel Swanjaya1, Danar Putra Pamungkas ${ }^{2}$ \\ ${ }^{1,2}$ Teknik Informatika, Fakultas Teknik, Universitas Nusantara PGRI Kediri \\ ${ }^{3}$ Teknik Mesin, Fakultas Teknik, Universitas Nusantara PGRI Kediri \\ E-mail: $\underline{* 1}$ GenerationJournal@unpkediri.ac.id, ${ }^{2}$ danar@unpkediri.ac.id.,
}

\begin{abstract}
Abstrak - Penjualan Pakan Kucing di Toko PS menjadi perhatian utama Pemilik Toko karena antusias pemilik kucing untuk membeli Pakan Kucing sangat tinggi. Tetapi karena persaingan usaha menyebabkan penjualan Pakan Kucing menjadi tidak menentu sehingga pemilik kesulitan dalam pengadaan barang. Penelitian ini memprediksi penjualan pakan kucing Whiskas Tuna Junior dan Bolt Ikan di Toko PS menggunakan metode Least Square. Hasil prediksi dianalisa dengan metode korelasi dan MAPE untuk mengetahui tingkat keberhasilan prediksi. Nilai korelasi yang didapat rendah yaitu antara 0 - 0,2 dan nilai MAPE 41,8\% dan 56,3\% masuk kategori wajar dan tidak akurat. Sehingga metode Least Square tidak sesuai digunakan untuk memprediksi untuk data acuan yang fluktuatif dan dengan periode yang pendek yaitu tanggal atau hari pada kasus Toko PS
\end{abstract}

Kata Kunci - prediksi, penjualan, least square

\begin{abstract}
The sale of cat feed in Toko PS is the main concern of Shop Owners because of the very high enthusiasm of cat owners to buy Cat Feed. However, due to business competition, the sale of Cat Feed is not decisive, so the owner has difficulty in procuring goods. This research predicts the selling of food products in Toko PS using the Least Square method. The results were analyzed using the standby method and MAPE to see the prediction alert level. The obtained values obtained were low, namely between $0-0.2$ and the MAPE values of $41.8 \%$ and $56.3 \%$ were categorized as fair and inaccurate. So that the Least Square method is not suitable for predicting to predict fluctuating reference data and with a short period, namely the date or day in the case of Toko PS.
\end{abstract}

Keywords - prediction, sale, least square

\section{PENDAHULUAN}

Petshop adalah salah satu bentuk Usaha Kecil dan Menengah (UKM) yang bergerak di bidang pemeliharaan, perawatan dan penjualan hewan. Semakin banyaknya orang yang kini memelihara hewan peliharaan membuat bisnis Petshop semakin subur, salah satunya adalah Toko PS, salah satu Petshop di Kota Kediri. Saat ini Kucing merupakan salah satu hewan yang banyak dipelihara oleh manusia. Kucing dapat menjadi teman di saat manusia merasakan kesepian. Perilaku kucing yang imut dan menggemaskan dapat membuat pemiliknya menjadi terhibur. Memelihara kucing bahkan saat sekarang ini sudah menjadi gaya hidup kosmopolitan yang serba praktis bagi sebagian orang [1]. Hal ini membuat penjualan Pakan Kucing di Toko PS menjadi perhatian utama Pemilik Toko karena antusias pemilik kucing untuk membeli Pakan Kucing sangat tinggi. Tetapi karena persaingan usaha menyebabkan penjualan Pakan Kucing menjadi tidak menentu sehingga pemilik kesulitan dalam pengadaan barang, karena beberapa Pakan memiliki Tanggal Kadaluarsa yang berbeda-beda dan penyimpanannya tidak bisa sembarangan, sehingga pemiliki lebih cermat dalam pengadaan Pakan dan dapat meminimalisir kerugian.

Sistem Prediksi Harga Bekatul menggunakan Metode Fuzzy Time Series digunakan pada Perusahaan Konsentrat Pakan Ternak yang memproduksi Bekatul. Sistem yang dibuat oleh Oky Krisdiantoro pada tahun 2019 ini digunakan untuk memprediksi harga bekatul di bulan yang akan datang dan prediksi terbaik menghasilkan nilai Mean Absolute Percentage Error (MAPE) sebesar 4,43\% dengan jumlah data latih 36 dan panjang interval 12 [2]. Pada tahun 2019 Erni Widajanti 
menggunakan metode Least Square untuk memprediksi penjualan susu perah di KUD. Cepogo Kabupaten Boyolali. Peramalan permintaan susu digunakan untuk mengetahui berapa perkiraan kebutuhan konsumen akan susu perah yang selanjutnya hasil peramalan permintaan digunakan untuk mengambil keputusan berapa banyak susu sapi yang harus diproduksi. Data yang digunakan adalah data penjualan susu dari tahun Januari 2014 sampai Agustus 2019. Persamaan yang dihasilkan digunakan untuk meramalkan penjualan dari bulan September 2019 hingga Desember 2019 [3]. Aris Purwanto membuat Sistem Peramalan Produksi Jagung Menggunakan Metode Double Exponential Smoothing untuk wilayah Provinsi Jawa Barat pada tahun 2020. Data yang digunakan adalah data Produksi jagung di Provinsi Jawa Barat selama tahun 1993-2015. Sistem yang dibuat digunakan untuk memprediksi produksi Jagung pada tahun yang akan datang. Pada penelitiannya pengujian dilakukan dengan cara membandingkan nilai MAPE dari setiap parameter alfa 0.1 sampai 0.9 . Selanjutnya akan diambil nilai MAPE yang paling kecil, dimana MAPE terkecilnya adalah $8.57 \%$ pada alfa 0.4 [4]. Naik turunnya harga bahan pangan membuat Nindian Puspa Dewi membuat Sistem Peramalan Harga Bahan Pangan di Kabupaten Pamekasan menggunakan metode Holt-Winter Exponential pada tahun 2020. Data harga bahan pangan yang dijadikan dataset dalam penelitian ini adalah data harga daging ayam broiler, kentang, telur, bawang merah, gula dan beras di Kabupaten Pamekasan, dari Bulan Januari 2012 sampai dengan Desember 2019 [5]. Maissy Della Danianty dalam penelitiannya menggunakan Metode Least Square untuk memprediksi jumlah kebutuhan obat UPTD Puskesmas Pontianak Selatan. Metode Least Square merekayasa jumlah kuadrat dari semua titik-titik vertikal (residu) antara titik-titik koordinat dan garis trend menjadi se-minimal mungkin. Data stok obat yang digunakan dalam penelitian adalah data dari Januari 2017 sampai dengan Desember 2018. Data yang digunakan sebanyak 20 jenis obat yang sering dikonsumsi, Persentase tingkat akurasi keberhasilan sistem keseluruhan obat secara ratarata adalah sebesar 93,49\% [6].

Pada penelitian ini akan menganalisa hasil prediksi penjualan Pakan Kucing pada masa akan datang dengan menggunakan metode Least Square dan untuk mengetahui tingkat keberhasilan dari hasil prediksi diguna.kan metode Korelasi dan MAPE. Proses prediksi menggunakan metode Least Square karena Least Square adalah suatu metode yang paling luas digunakan untuk menentukan persamaan trend data. Data yang digunakan untuk penelitian ini adalah data penjualan Pakan Kucing Whiskas Tuna Junior dan Bolt Ikan mulai dari tanggal 1-30 September 2020. Data yang digunakan untuk untuk uji tingkat kerberhasilan prediksi yaitu data hasil penjualan tanggal 115 Oktober 2020.

\section{METODE PENELITIAN}

\subsection{Tahapan penelitian}

Penelitian ini melalui beberapa tahapan seperti berikut :

a. Studi Literatur

Pada tahap ini mempelajari teori-teori yang akan digunakan dalam penelitian yaitu peramalan, peramalan penjualan dan metode Least Square. Selain itu juga mencari penelitian penelitan terdahulu yang relevan dengan penelitian yang dilakukan.

b. Pengambilan Data

Data yang digunakan merupakan data primer. Data yang digunakan untuk penelitian ini merupakan data penjualan Pakan Kucing Whiskas Tuna Junior dan Bolt Ikan mulai dari tanggal 1-30 September 2020 dan 1-15 Oktober 2020 pada Toko PS.

c. Proses Prediksi

Pada tahap ini data penjualan Pakan Kucing Whiskas Tuna Junior dan Bolt Ikan tanggal 1-30 September 2020 diolah menggunakan metode Least Square, untuk mendapatkan prediksi penjualan pada tanggal 1-15 Oktober 2020.

d. Analisa Hasil Prediksi

Perhitungan korelasi dan error dilakukan untuk mengetahui tingkat keberhasilan prediksi dengan metode korelasi dan MAPE, dengan cara membandingkan hasil prediksi dengan data hasil penjualan sebenarnya. 


\subsection{Studi Literatur}

\subsubsection{Peramalan}

Peramalan (forecasting) yaitu proyeksi tentang tingkat permintaan konsumen pada suatu periode tertentu dengan menggunakan berbagai asumsi tertentu, atau suatu cara untuk menaksir kondisi bisnis di masa yang akan datang berdasarkan data yang pernah terjadi [7]. Peramalan (forecasting) permintaan akan produk dan jasa di waktu mendatang dan bagian-bagiannya sangat penting dalam perencanaan dan pengawasan produksi. Suatu peramalan banyak mempunyai arti, maka peramalan tersebut perlu direncanakan dan dijadwalkan sehingga akan diperlukan suatu kebijaksanaan untuk menetapkan beberapa hal yang mempengaruhinya. Memprediksi penjualan adalah masalah yang cukup kompleks dalam pembelajaran mesin. Selama pandemi COVID-19, beberapa sektor komersial tertentu sangat terpengaruh, ke berbagai arah, oleh kebijakan Lockdown yang telah menyebar di dunia [8].

\subsubsection{Data Time Series}

Data time series merupakan data yang disusun dari waktu ke waktu dari objek tertentu dengan tujuan untuk menggambarkan perubahan data. Dalam Ilmu Ekonomi terdapat istilah variasi time series, yaitu fluktuasi/variasi dari waktu ke waktu. Variasi ini biasanya disebabkan oleh adanya faktor Trend (trend factor), Fluktuasi siklis (cyclical fluctuation), Variasi musiman (seasonal variation), dan pengaruh random (irregular/random influences) [9].

\subsubsection{Pakan Kucing}

Jenis makanan kucing memang tersedia dalam berbagai bentuk. Sebagai hewan peliharaan, kucing biasanya memerlukan nutrisi sehat dan seimbang pada makanannya. Terdapat beberapa jenis makanan kucing yang bisa diberikan. Makanan terbaik untuk kucing sepenuhnya tergantung pada kebutuhan mereka. Sebagai aturan umum, makanan tinggi protein, rendah karbohidrat, dan dikemas dengan mineral dan vitamin untuk mendukung hidup sehat merupakan pilihan yang ideal. Jenis makanan kucing ini bisa didapatkan di pet shop atau bahkan dibuat sendiri di rumah. Jenis makanan kucing biasanya juga disesuaikan dengan umur dan kebutuhan kucing. Jenis makanan kucing yang tepat akan mempercepat pertumbuhan kucing dan menjaga kesehatannya [10].

\subsubsection{Metode Least Square (Kuadrat Terkecil)}

Pada analisa time series terdapat metode Free Hand, metode Semi Average, Metode Moving Average dan metode Least Square. Metode peramalan (forecasting) kuadrat terkecil atau yang biasa disebut sebagai metode Least Square, adalah metode peramalan yang menggunakan persamaan linear untuk menemukan garis paling sesuai untuk kumpulan data lampau guna meramalkan data di masa depan. Metode menggunakan data yang berupa data deret berkala atau time series [11]. Metode least square dibagi menjadi dua kasus, yaitu kasus data genap dan kasus data ganjil. Pada umumnya persamaan garis linear time series dapat dirumuskan seperti Persamaan 1.

Keterangan ;

$$
\mathrm{Y}=\mathrm{a}+\mathrm{bx}
$$

Y : Jumlah Penjualan

a dan $\mathrm{b}:$ Koefisien

$\mathrm{x} / \mathrm{t} \quad$ : waktu tertentu dalam bentuk kode

dalam menentukan nilai $\mathrm{x} / \mathrm{t}$ seringkali digunakan teknik alternatif dengan memberikan skor atau kode. Dalam hal ini dilakukan pembagian data menjadi dua kelompok, yaitu :

Data genap, maka skor nilai t nya : ...,-5, $-3,-1,1,3,5, \ldots$

Data ganjil, maka skor nilai t nya : ...,-3,-2, $-1,0,1,2,3, \ldots$

Kemudian untuk mengetahui koefisien a dan b dicari dengan persamaan 2 dan 3 .

$$
a=\frac{\sum Y}{n}
$$




$$
b=\frac{\sum t Y}{\sum t^{2}}
$$

Untuk pengetahui hasil prediksi maka menggunakan persamaan (4)

$$
Y^{\prime}=Y\left(\left(\frac{T}{R}\right) / c\right)
$$

Keterangan :

$\mathrm{Y}^{\prime}=$ Hasil prediksi

$\mathrm{T}=$ Jumlah periode tertentu

$\mathrm{R}=$ rata-rata penjualan pada periode tertentu

$\mathrm{C}=$ rata-rata penjualan

\subsubsection{Koefisien Korelasi Sepasang Data}

Korelasi berguna untuk menghitung matriks koefisien korelasi dari sekumpulan set data(variabel) yang diasumsikan berasal dari hasil pengukuran secara indepeden. Koefisien korelasi antara $\mathrm{X}$ dan $\mathrm{Y}$ menentukan apakah nilai-nilai kedua variabel bergerak secara bersamaan, yakni semakin besar nilai $\mathrm{X}$ semakin besar pula nilai $\mathrm{Y}$ (korelasi positif) atau sebaliknya, semakin besar nilai X semakin kecil nilai Y (korelasi negatif), atau keduanya tidak saling berhubungan (korelasi nol). Untuk mengetahui nilai korelasi dengan menggunakan persamaan (5)

$$
r_{X, Y}=\frac{\operatorname{cov}(X, Y)}{s_{X} s_{y}}
$$

\subsubsection{Mean Absolute Percentage Error (MAPE)}

Metode MAPE merupakan ukuran keteparan relatif yang digunakan untuk mengetahui prosentase penyimpangan hasil prediksi, dengan persamaan (6) dan (7)

$$
M A P E=\frac{1}{n} \sum \sum_{i=1}^{n}|P E i|
$$

Persentase Error

$$
P E_{t}=\left(\frac{X_{t}-F}{X_{t}}\right) \times 100 \%
$$

\section{HASIL DAN PEMBAHASAN}

Data yang digunakan dalam penelitian ini merupakan data hasil penjualan selama bulan September 2020 dua produk terlaris di Toko PS yaitu Pakan Kucing Whiskas Tuna Junior dan Bolt Ikan. Data dimulai pada tanggal 1 hari selasa sampai dengan tanggal 30 hari rabu bulan September 2020. Data pada bulan tersebut digunakan sebagai acuan untuk memprediksi penjualan pada dua pekan awal bulan Oktober 2020 yaitu tanggal 1-14. Data hasil penjualan bulan September dapat dilihat pada tabel 1 .

Tabel 1. Data Penjualan Bulan September 2020

\begin{tabular}{cccccc}
\hline Tanggal & Bolt Ikan & Whiskas Tuna Junior & Tanggal & Bolt Ikan & Whiskas Tuna Junior \\
\hline 1 & 40 & 18 & 16 & 21 & 13 \\
2 & 28 & 20 & 17 & 23 & 21 \\
3 & 0 & 0 & 18 & 19 & 18 \\
4 & 35 & 24 & 19 & 34 & 28 \\
5 & 20 & 30 & 20 & 40 & 21 \\
6 & 41 & 12 & 21 & 16 & 22 \\
7 & 29 & 28 & 22 & 28 & 11 \\
8 & 39 & 13 & 23 & 23 & 33 \\
9 & 36 & 8 & 24 & 20 & 14 \\
10 & 20 & 23 & 25 & 20 & 30 \\
11 & 29 & 33 & 26 & 26 & 24 \\
12 & 49 & 10 & 27 & 25 & 16 \\
13 & 32 & 24 & 28 & 19 & 24 \\
14 & 32 & 23 & 29 & 23 & 18 \\
15 & 24 & 18 & 30 & 0 &
\end{tabular}


Pada gambar 1 dan 2 merupakan data hasil penjualan bulan September 2020 disajikan dalam bentuk grafik. Penjualan hasil penjualan produk Whiskas Tuna Junior dari tanggal 1 sampai dengan 30 menandakan fluktuatif, data grafik dapat dilihat pada gambar 1. Pada gambar 2 menunjukan hasil penjualan produk Bolt Ikan mirip dengan hasil penjualan Whiskas Tuna Junior yaitu fluktuatif.

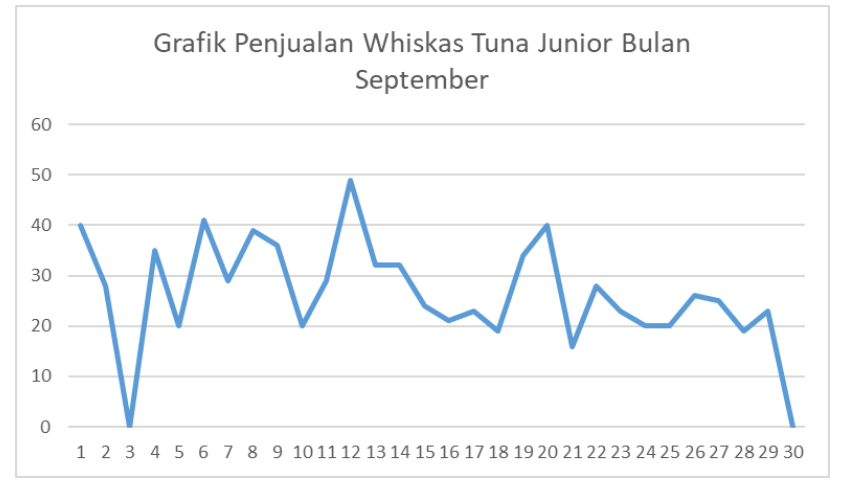

Gambar 1. Grafik Penjualan Whiskas Tuna Junior Bulan September

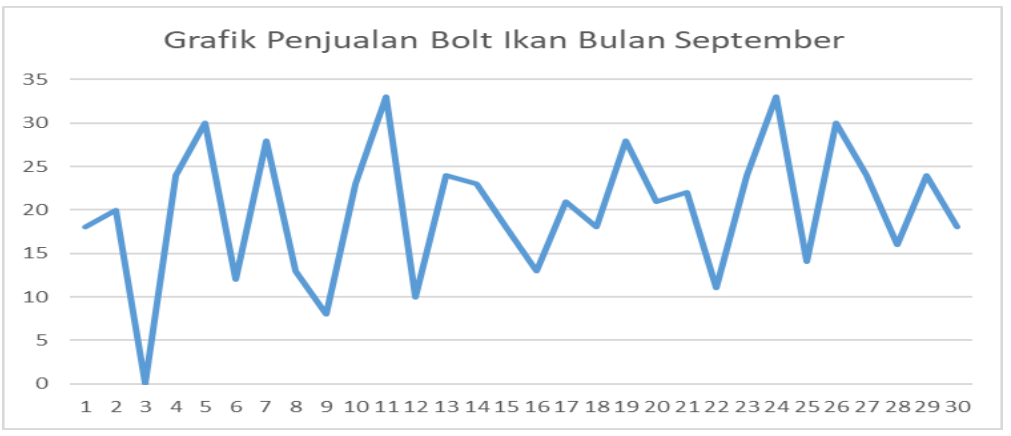

Gambar 2. Grafik Penjualan Bolt Ikan Bulan September

Tabel 2. Data Hasil Prediksi Penjualan Bulan Oktober 2020

\begin{tabular}{ccr}
\hline Tanggal & Bolt Ikan & Whiskas Tun \\
\hline 1 & 12 & 22 \\
2 & 19 & 26 \\
3 & 23 & 28 \\
4 & 24 & 24 \\
5 & 16 & 26 \\
6 & 20 & 20 \\
7 & 14 & 20 \\
8 & 10 & 23 \\
9 & 16 & 27 \\
10 & 19 & 30 \\
11 & 20 & 25 \\
12 & 13 & 27 \\
13 & 17 & 21 \\
14 & 11 & 21 \\
15 & 12 & 22
\end{tabular}

Dari tabel 1 dengan menggunakan persamaan (2) didapat nilai $a$ produk Whiskas Tuna Junior yaitu 20 sedangkan Produk Bolt Ikan 26,37. Nilai $b$ produk Whiskas Tuna Junior yaitu 0,09 
sedangkan Produk Bolt Ikan -0,22 dengan menggunakan persamaan (3). Jika untuk meprediksi hasil penjualan pada tanggal 1 Oktober pada hari kamis maka nilai $\mathrm{x}$ adalah 31 maka diapat hasil prediksi menggunakan persamaan (4) Y' produk Whiskas Tuna Junior didapat nilai 22 sedangkan produk Bolt Ikan 12. Jika untuk memprediksi hasil penjualan pada tanggal 2 Oktober pada hari Jumat, maka nilai $\mathrm{x}$ adalah 33, sehinga didapat nilai $\mathrm{Y}^{\prime}$ untuk produk Bolt Ikan dan Whiskas Tuna Junior berturut-turut adalah 26 dan 19. Untuk hasil prediksi pada tanggal 1 sampai dengan 15 bulan Oktober dapat dilihat pada tabel 2 .

Untuk mengetahui tingkat keberhasilan hasil prediksi, maka data pada tabel 2 akan dibandingkan dengan data hasil penjualan sebenarnya yaitu pada tabel 3.

\begin{tabular}{ccc}
\multicolumn{3}{c}{ Tabel 3 Data Hasil Penjualan Bulan Oktober 2020} \\
\hline Tanggal & Bolt Ikan & Whiskas Tuna Junior \\
\hline 1 & 28 & 12 \\
2 & 41 & 17 \\
3 & 34 & 24 \\
4 & 23 & 6 \\
5 & 22 & 36 \\
6 & 37 & 13 \\
7 & 20 & 21 \\
8 & 14 & 29 \\
9 & 39 & 38 \\
10 & 12 & 14 \\
11 & 27 & 22 \\
12 & 34 & 20 \\
13 & 30 & 21 \\
14 & 26 & 33 \\
15 & 28 & 12
\end{tabular}

Perbandingan antara hasil prediksi dengan penjulan produk Bolt Ikan terlihat berbeda seperti pada gambar 3. Perbedaan tersebut dapat dilihat dari trend hasil penjualan yang tidak menentu atau fluktuatif, sedangkan hasil prediksi menunjukkan trend cenderung menurun. Jarak antara grafik hasil penjualan dengan hasil prediksi juga cukup jauh. Perbandingan antara penjulan produk Whiskas Tuna Junior dengan hasil prediksi juga ada perbedaan. Pada hasil penjualan menunjukkan trend yang tidak menentu atau fluktutif, sedangkan hasil prediksi menunjukkan trend cenderung stabil. Jarak antara grafik hasil penjualan dengan prediksi juga cukup jauh seperti pada gambar 4.

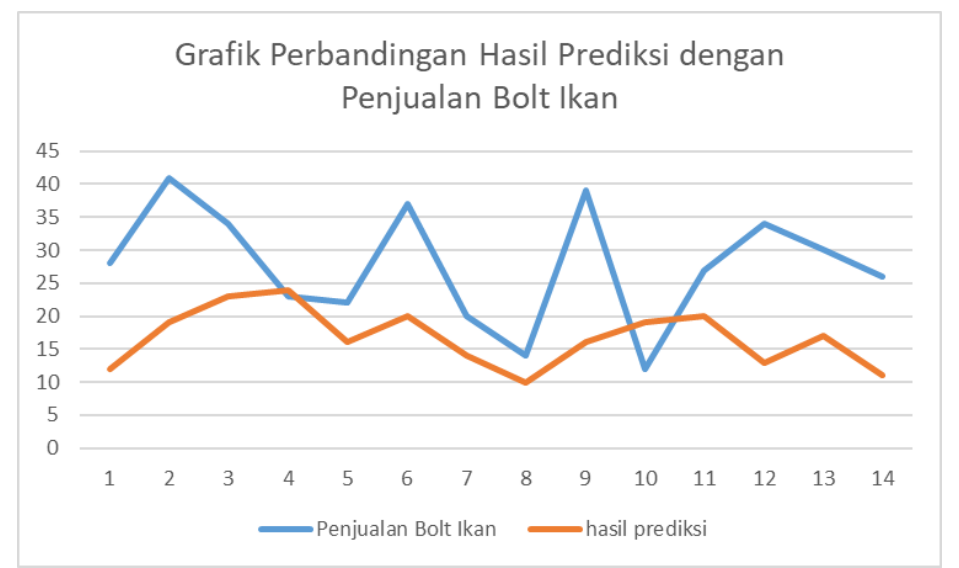

Gambar 3. Grafik perbandingan hasil prediksi dengan penjualan Bolt Ikan 


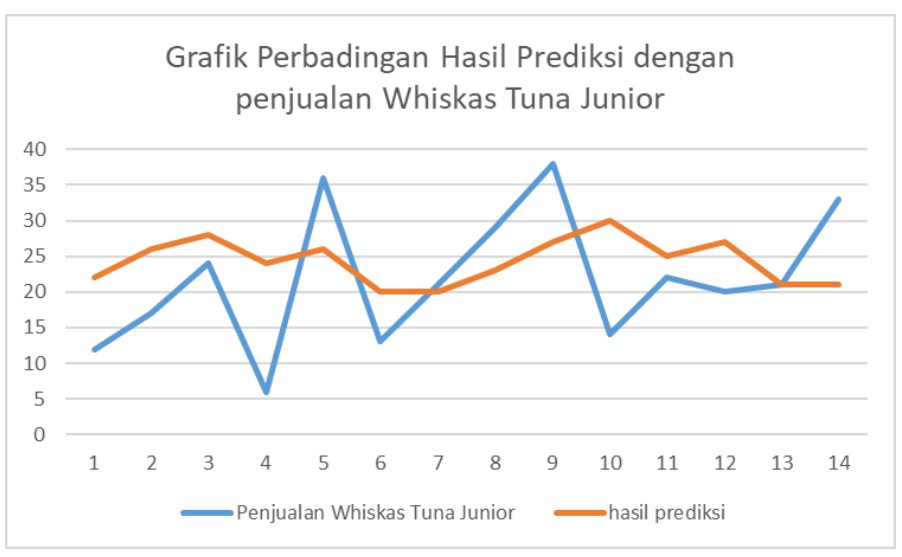

Gambar 4. Grafik perbandingan hasil prediksi dengan penjualan Whiskas Tuna Junior

Dalam melakukan prediksi terjadi ketidaksesuaian antara hasil penjualan dengan hasil prediksi, oleh karena itu dilakukan perhitungan korelasi dan error untuk mengetahui tingkat keberhasilan prediksi dengan metode korelasi dan MAPE.

Tabel 4. Hasil Perhitungan Korelasi dan MAPE

\begin{tabular}{lcc}
\hline \multicolumn{1}{c}{ Produk } & Korelasi & MAPE \\
\hline Bolt Ikan & 0,2 & $41,8 \%$ \\
Whiskas Tuna Junior & 0,1 & $56,3 \%$
\end{tabular}

Berdasarkan hasil perhitungan nilai korelasi dan MAPE pada tabel 4, diketahui kedua produk memiliki nilai korelasi antara 0 - 0,2. Nilai tersebut menandakan bahwa korelasi antara hasil prediksi dengan hasil penjualan rendah. Sedangkan nilai MAPE produk Bolt Ikan yaitu 41,8\% yang masuk dalam kategori wajar, sedangan produk Whiskas Tuna Junior bernilai 56,3\% masuk kategori tidak akurat. Hasil tersebut didapat karena periode prediksi yang digunakan yaitu perhari atau tanggal yang menyebabkan data acuan prediksi tidak menentu atau fluktuatif. Selain itu data yang digunakan hanya 30 hari sehingga belum terlihat trend hasil penjualan. Oleh karena itu metode Least Square tidak sesuai digunakan untuk memprediksi untuk data acuan yang fluktuatif dan dengan periode yang pendek yaitu tanggal atau hari pada kasus Toko PS.

\section{SIMPULAN}

Dari hasil perhitungan prediksi dan hasil penjualan dapat disimpulkan sebagai berikut :

1. Nilai korelasi yang didapat rendah yaitu antara $0-0,2$ dan nilai MAPE $41,8 \%$ dan $56,3 \%$ masuk kategori wajar dan tidak akurat.

2. Metode Least Square tidak sesuai digunakan untuk memprediksi untuk data acuan yang fluktuatif dan dengan periode yang pendek yaitu tanggal atau hari pada kasus Toko PS.

\section{SARAN}

Saran-saran untuk untuk penelitian selanjutnya yaitu :

1. Perlu penambahan data acuan yang lebih banyak, misalnya enam bulan.

2. Perlu dilakukan memprediksi dengan periode yang lebih panjang, misalanya per pekan. 


\section{DAFTAR PUSTAKA}

[1] Effendi, Cacang dan Widya Setiawati. 2017. Solusi Permasalahan Kucing. Penebar Swadaya: Jakarta

[2] Krisdiantoro, Oky, Budi Darma Setiawan, and Muhammad Tanzil Furqon. "Prediksi Harga Bekatul Menggunakan Metode Fuzzy Time Series." Jurnal Pengembangan Teknologi Informasi dan Ilmu Komputer e-ISSN 2548 (2019): 964X.

[3] Widajanti, Erni, and Suprayitno Suprayitno. "Implementasi Metode Least Square Untuk Memprediksi Penjualan Susu Perah (Studi Pada Kud Cepogo Kabupaten Boyolali)." Research Fair UNISRI 4.1 (2020).

[4] Purwanto, Aris, and Siti Nurul Afiyah. "Sistem Peramalan Produksi Jagung Provinsi Jawa Barat Menggunakan Metode Double Exponential Smoothing." Jurnal Ilmiah Teknologi Informasi Asia 14.2 (2020): 85-92.

[5] Dewi, Nindian Puspa, and Indah Listiowarni. "Implementasi Holt-Winters Exponential Smoothing untuk Peramalan Harga Bahan Pangan di Kabupaten Pamekasan." Digital Zone: Jurnal Teknologi Informasi Dan Komunikasi 11.2 (2020): 219-231.

[6] Della Danianty, Maissy, Cucu Suhery, and Rahmi Hidayati. 2020. "Prediksi Jumlah Kebutuhan Obat Menggunakan Metode Least Square Berbasis Website (Studi Kasus: UPTD Puskesmas Pontianak Selatan)." Coding Jurnal Komputer dan Aplikasi 8.2.

[7] Cristania, Matteo, Luca Pasettoa, and Claudio Tomazzolia. "A knowledge-intensive methodology for explainable sales prediction." Procedia Computer Science 176 (2020): 1180-1187.

[8] Putra, H.P. dan Rachman, F.H. 2013. "Sistem Peramalan Distribusi Beras Menggunakan Metode Exponential Smoothing", Jurnal Teknik Informatika 1: 1-8.

[9] Siswanto, V. A. 2012. "Strategi dan Langkah - Langkah Penelitian". Yogyakarta: Graha ilmu.

[10] Widyananda, Rakha Fahreza. "4 Jenis Makanan Kucing dan Cara untuk Memilih yang Tepat" merdeka.com, 24 April 2020. (https://www.merdeka.com/jatim/4-jenis-makanan-kucing-dan-carauntuk-memilih-yang-tepat-kln.html). Diakses tanggal 10 Desember 2020.

[11] Boedijoewono, Noegroho. "Pengantar statistik ekonomi dan perusahaan. Jilid Dua". Unit Penerbit dan Percetakan AMP YKPN, 2001. 